\title{
The Influence of Applying Non-mainstream Social Resources on the Development of College Art Professional Courses
}

\author{
Xiaoxi Song \\ Guangxi University of Science and Technology, Liuzhou City, Guangxi Zhuang Autonomous Region, 545006
}

Abstract: As an important art in human activities, art can not only reflect the objective world, but also enrich the power of human nature. This is a kind of free character. People can fully integrate their emotions and imaginations in art activities, and learn from the inside. To achieve harmony and pleasure outside. Aesthetics is the dominant in fine arts, and at the same time it forms an integrated network system with various non-aesthetic functions. This system can reflect human development and the construction of human aesthetic psychology. At present, more and more people recognize the non-mainstream Social resources have a certain influence on the quality of people. Therefore, in the development of college art majors, the application of non-mainstream social resources also has a certain impact.

Keywords: Non-Mainstream Social Resources; College Art Professional Courses; Influence

From the perspective of fine arts, domestic art education pays more attention to the cultivation of skills, especially original concepts, which must be developed after skills are developed. Therefore, in a sense, Chinese art education can be seen to be strict imitate. This is closely related to traditional teaching concepts. The excessive use of teachers as the core of the classroom in the teaching process and high scores in exams as the learning goals of students are obviously contrary to the people-oriented concept of modern education. Under the new situation Teachers in colleges and universities need to pay full attention to students' dominant position in the classroom, adopt a variety of teaching and practical activities, cultivate students' innovative spirit and art practice ability, and promote students' all-round development.

\section{The importance of non-mainstream social resources in the development of college art professional courses}

In fact, social development is an immortal theme. The whole country is working hard for the great rejuvenation of the Chinese nation. Therefore, how to take effective measures to promote economic, cultural, educational, and political progress is the strong will of every Chinese nowadays. In the process of human development, the implementation of a sustainable development strategy is an objective need, and it is also an inevitable choice for our country to follow the trend of the times in the development process. Throughout the development of the entire human society, due to the different periods, different stages of development, different regions, differences in productivity levels and other reasons, the perception and requirements for the development concept are also completely different. How to clearly understand the specific situation in the current region, take reality as the starting point, emancipate the mind, persist in seeking truth from facts, keep pace with the times, and establish an objective and practical scientific outlook on development is very important for art learning. Therefore, on this basis, the application of non-mainstream social resources in art teaching in colleges and universities is particularly critical.

\section{The application of non-mainstream social resources in the courses of college art majors}

Copyright (C) 2020 Xiaoxi Song

doi: 10.18282/le.v9i7.1499

This is an open-access article distributed under the terms of the Creative Commons Attribution Non-Commercial License

(http://creativecommons.org/licenses/by-nc/4.0/), which permits unrestricted non-commercial use, distribution, and reproduction in any medium, provided the original work is properly cited. 


\subsection{Expand knowledge, divergent thinking}

With the rapid development of science and technology, the knowledge economy has gradually emerged in the current society. The development and reform of education under fierce international competition has a pivotal role for all countries in the world. In the face of new situations and new conditions, on the one hand, it has brought New tasks and new problems also call for new countermeasures and new ideas. In education, innovative educational concepts must be adopted to reform my country's current education and provide new guidance for the development of my country's education. Therefore, college art courses began to focus on changes beyond the integration of subject knowledge, began to attach importance to the main role of students in the entire development process, and paid attention to the organic connections between disciplines and between disciplines and a wider range, through expansion The knowledge of students promotes the divergence of students' thinking, improves students' creativity, and helps students develop comprehensive abilities.

\subsection{Integration of sustainable development concepts}

In the teaching stage of colleges and universities, each discipline emphasizes independence and professionalism, and the discipline-based concept leads students to a more professional depth, and this systematic teaching makes the connection between disciplines looser. The closed nature of the students is also getting heavier and heavier academic pressure. Nowadays, the education sector is increasingly emphasizing the comprehensive development of university teaching and advocating cross-border integration among various disciplines, which can also enable students to have a more comprehensive understanding of knowledge. Driven by the trend, art courses in colleges and universities should also be integrated, uphold the concept of sustainable development, and attach importance to the cultivation of compound talents. The application of non-mainstream social resources can speed up this process and make the transformation of art courses in colleges and universities faster and more efficient.

\subsection{Closely focus on course objectives}

The application of non-mainstream social resources makes the art professional courses of colleges and universities more integrated, which makes the curriculum goals easier to achieve, and at the same time makes the curriculum goals more systematic. It can refine the overall goal into branch goals, and then transform the branch goals into specific goals through humanistic theme activities and different discipline activities, and guide students step by step to achieve the overall goals, thereby improving the structure of the college art professional curriculum, Make it play a greater educational function.

\subsection{Promote the integrated development of art courses}

Comprehensiveness is a characteristic of every subject. The comprehensive and coordinated use of knowledge of various subjects in the teaching process is more conducive to students' understanding of professional knowledge. In art courses in colleges and universities, integrating non-mainstream social resources can effectively improve the comprehensiveness of art courses and make it easier for students to learn art. This is not only an efficient teaching method, but also an advanced teaching concept. If you want to use non-mainstream social resources to achieve the comprehensive development of college art courses, you need to pay attention to the logic of application and grasp the logical relationship of teaching content. Specifically, first, we should pay attention to affection in application, and make art teaching more warm and active through non-mainstream social resources, so that students can more intuitively feel human emotion and intuition from art learning. Secondly, through the weakening of knowledge goals, the strengthening of human goals is achieved. The English knowledge goal of art teaching is a teaching method, and more attention is paid to cultivating students' comprehensive qualities and abilities during the journey of acquiring knowledge goals. Thirdly, flexible teaching should be emphasized in application, to reduce the overall difficulty of art professional courses, so that students can get a sense of accomplishment more easily, and at the same time, make art courses open to all students. Finally, to strengthen the logic and rhythm of professional curriculum teaching is the overlapping of guiding and performance goals.

\section{Concluding remarks}


Art education has always been a subject full of artistry and humanity. In art education, people-oriented is fully reflected. The cultivation of people is the unchangeable educational goal of art education, and the ultimate pursuit of art education is to provide people with eternal education. In the development process of art education, adhering to the concept of comprehensive, coordinated and sustainable development, non-mainstream social resources will play a very high role in promoting it. The application of non-mainstream social resources in art courses in colleges and universities can increase the compatibility and innovation of art education, so that every educated person can be developed in an allround way, and the art courses in colleges and universities can be better developed.

\section{References}

1. Guo Liang. Analysis of the status quo of the quality of talent training in art colleges and universities and improvement measures[J]. High Education Journal, 2020(30):141-143.

2. Wen Zhenxin. On the reform and innovation of the teaching mode of art major courses in colleges and universities[J]. Art Education Research, 2020(17): 150-151.

3. Chai Hongxia. Discussion on the training model of postgraduates majoring in art teaching in colleges and universities[J]. China Packaging, 2020, 40(09): 66-71. 